\title{
The History of Contemporary Indonesian Muslim Groups and Muslim Media
}

\section{TWEDIANA BUDI HAPSARI}

Universitas Muhammadiyah Yogyakarta

Email: twediana@umy.ac.id

\section{ABSTRACT}

Indonesia as the most populous M uslim country in the world is always interesting to be explored. $\mathrm{N}$ ot only consist of more than 300 local ethnics, but also as the third most democratic country after India and U SA . H owever, Indonesian M uslims are diverse into different groups, which started from the early 20 s century, and also developed their own M uslim media channels. H owever, it seems that the political change in Indonesia has biggest influence to the growth of M uslim groups in Indonesia. Therefore, this article attempts to describe this influence into both M uslim groups and media from early $1900 \mathrm{~s}$ to 2010.

K eyword: Indonesia, M edia, M oslem

\section{ABSTRAK}

Indonesia sebagai negara M uslim paling banyak di dunia selalu menarik untuk dieksplorasi. Tidak hanya terdiri dari lebih dari 300 etnis lokal, tetapi juga sebagai negara paling demokratis ketiga setelah India dan A merikaSerikat. N amun, umat Islam Indonesia beragam ke dalam kelompok yang berbeda, yang dimulai dari awal abad 20, dan juga mengembangkan saluran media M uslim mereka sendiri. Namun, tampaknya perubahan politik di Indonesia memiliki pengaruh terbesar terhadap pertumbuhan kelompok M uslim di Indonesia. O leh karena itu, artikel ini mencoba menggambarkan pengaruh ini ke dalam kelompok dan media M uslim dari awal 1900-an hingga 2010.

Kata Kunci: Indonesia, M edia, M uslim

\section{INTRODUCTION}

Indonesia is the world's largest M uslim society. According to the 2010 PEW Research Report, $60 \%$ of the Muslim world's population is from the Asia-Pacific, of which $20.37 \%$ lives in Indonesia. ${ }^{1}$ Allowing to the census 
data released by Biro Pusat Statistik Indonesia (Indonesian Statistics Bureau) in 2010, the number of Muslim inhabitants of Indonesia is $207,176,162$, which is $87.2 \%$ of all Indonesian citizens. Within this large society, several M uslim groups are existed that contributes to variety practices of Islamic thought. On the other side, the growth of M uslim media also following the growth of these groups, since most of the Muslim media are administered by M uslim activists from each group. This article will provide a historical overview of Indonesian Muslim groups and media.

The earliest evidence of Islam was found on a gravestone with a Muslim date of 1082 in Leran, East Java. ${ }^{2}$ Further proof came from Marco Polo's report about his travels in Sumatra (one of the largest islands in Indonesia) around 1292. He stated that there was a Muslim community founded by 'Moorish' traders at Perlak. He also found Muslim influence in tombstone names, such as 'Malik AI Shalih' from nearby 'Samudra Pasai' port. 'Samudra Pasai' is now known as Aceh. ${ }^{4}$

The spread of Islam in Indonesia grew with the increasing European demand for Indonesian herbs and spices from the $13^{\text {th }}$ century onwards. M uslim traders from Egypt, Yemen, and Gujarat played important roles in spreading Islamic values through international trading routes from Indonesia to Europe at that time. Some areas in Indonesia, including northern Java, the Mollucas, and Srivijaya, became centres of spice trading.

Azumardi Azra (2002) explains three patterns of Islamisation in Indonesia. The first pattern was that certain cities became centres of trading and of Islamic communities. In such centres, the sovereigns converted to Islam. Subsequently the monarchy played an important role in Islamisation in their regions. The second pattern was that the elite from those kingdoms studied Islam at centres of Islamic education, such as Giri and Gresik in East Java. The third pattern was that Islamic kingdoms sup ported other non-Islamic kingdoms that wanted to take over other territory, provided that the non-Islamic kings converted to Islam. For example, support was given by the Demak monarchy to the Banjar kingdom that wanted to dominate the Daha kingdom after the king of the former converted to Islam.

Some factors helped Islam become the majority religion in Indonesia. According to Nurcholis Madjid, Indonesia is one of the countries that did not employ its military force for the purposes of spreading Islam. ${ }^{5}$ Pen- 
etration Pacifique (peaceful penetration) is known as the approach of Islamisation in this country, brought by Muslim traders from Arabia and India. Islam became a new trend and offered new political and economic opportunities. ${ }^{6}$ Furthermore, intermarriages between the traders and local residents facilitated mutual acculturation, including that of Islamic values.

Another factor that helped Islam spread easily in Indonesia was the simplicity of its teaching, which could easily be understood by local residents. ${ }^{7}$ The form of Islam at that time was syncretic and mystical, which was close to Hinduism and Buddhism, the predominant beliefs of the country. For this reason, it was easily possible to convert people to Islam in Indonesia (Madjid, 1996: Maemunah, 2006; Pringle, 2010). Also for this reason, Islamic values can be seen in Indonesian culture today. For instance, the names of months in Javanese were adapted from the Islamic calendar ${ }^{8}$, the Islamic features of the Hindu Tenggerese community ${ }^{9}$ were described by Robert Hefner, and the true story of two Javanese Islamic Kyais in Serat Cebolek was written by Kanjeng Raden Adipati Suryakusuma in 1892, in the form of 32 poems in Macapat (one of the famous forms of Javanese poems). ${ }^{10}$

The influence of Islam can be seen in the content of Pancasila (the five principles), the official ideology in Indonesia, even though the term itself is of Sanskrit origin. The first sila, 'believe in One God', resonates with 'M onotheism', which is in line with Islamic teaching that only believes in one God. Sukarno, the first Indonesian president, was such a worshipper. He was the inventor of Pancasila. Originally, Sukarno put the 'believe in One God' precept as the fourth sila, but this idea was rejected by politicians with an Islamic orientation. Another negotiation that took place between politicians with an Islamic orientation and Sukarno regarded the idea of 'nationalism', which was the original idea of the third principle, 'The Unity of Indonesia'. Muslims objected to 'nationalism' because it was against the concept of Islamic universalism and cosmopolitanism, and because it reminded them of the chauvinist nationalism of Germany and Japan.

When discussing Indonesia, one cannot exclude Islam as the major religion in this country. Some phases of Islamic movements have affected the history of this nation. This article will explain the phases of Muslim groups, from the rise of freedom pressure groups as a reaction to Dutch 
colonialism in Indonesia from the beginning of the $20^{\text {th }}$ century, to the era of reformation since the fall of Suharto and through the first 10 years of the $21^{\text {st }}$ century. This article also presents a brief history of Islamic media in each phase within Indonesian history from the beginning of the $20^{\text {th }}$ century. The authoritative power of each era seemed to influence the changing life of the majority of religious society in Indonesia.

\section{INDONESIAN MUSLIM GROUPS IN THE EARLY $20^{\text {TH }}$ CENTURY}

Modern Islamic movements in Indonesia first appeared in the early $20^{\text {th }}$ century, when a lot of M uslim leaders realised that it was impossible to compete with Dutch colonialism, Christian penetration, and other attempts to step forward while they still employed traditional efforts to establish Islamic influences. ${ }^{11}$ According to Deliar Noer, the root of modern Islamic movements has come from two substantial advances within Muslim societies: education and social movements on the one hand, and political movements on the other.

Syaikh Ahmad Khatib pioneered the modern education and social movements in Indonesia. He was born in Bukittinggi, Minangkabau, Sumatera in 1855. He continued his studies in Mecca in 1876 and became an Imam of Syafii mahzab in M asjid al Haram. Although he taught Syafii's mahzab, he never forbade his students to learn about M uhammad Abduh's concept of modernisation in Islam. ${ }^{12}$ Some of his students from Indonesia were Syaikh Muhammad Djamil Djambek, Haji Abdul Karim Amrullah, and Haji Abdullah Ahmad from M inangkabau, Kyai Haji Ahmad Dahlan from Java (the founder of M uhammadiyah), and some traditionalist leaders, such as Syaikh Sulaimanar-Rasuli from Bukittinggi, and Kyai Haji Hasjim Asj'ari, the founder of Tebu Ireng pesantren in East Java. Later, Kyai Asj'ari became the leader of NU. ${ }^{13}$

Syaikh Ahmad Khatib's students disseminated Islamic teaching when they returned from Mecca. They inspired other local Islamic leaders to establish new Islamic movements. They taught Islam in local traditional communities in Minangkabau, such as Syaikh Djambek and Haji Abdul Karim Amrullah. They published Islamic magazines, similarly to what Haji Abdullah Ahmad did with Al-M unir (1911-1916), Al-Akhbar (1913), and Al-Islam (1916).

Kyai haji Ahmad Dahlan founded Muhammadiyah in 1912 as a social Islamic organisation that still exists today. Some other new Islamic 
organisations launched included Al-Jam'iyat al-Khairiyah in Jakarta (1905), PersyarikatanUlama in M ajalengka, West Java (1912), Al-Irsyad in Jakarta (1913), Persatuan Islam (Persis) in Bandung (1920), and PersatuanM uslimin Indonesia (Indonesian Muslim Association) in Padang (1929). ${ }^{14}$

The political movements stemmed from the Ethical Policy applied under Dutch colonialism in Indonesia in 1901 . This policy was suggested by Snouck Hurgronje, ${ }^{15}$ the consultant for local residents' issues, to limit Islamic values for the middle class. ${ }^{16}$ Hurgronje recommended distinguishing between Islam as a religion and Islamists as anti-Dutch colonialists. As a religion, Islam was a set of moral guidelines that should be tolerated, similarly to the situation betw een Protestants and Catholics in the Netherlands itself. Related to this issue, he argued that Islam was not an enemy. The rebellion of Islam extremists in some areas might be caused by inappropriate Dutch policy, such as the restriction on the Pilgrimage to M ecca, and the oppression dealing with the 'fanatic' Islamist leaders.

On the other hand, Hurgronje acknowledged that the involvement of Javanese aristocracy and traditional leaders in the outer Javanese islands could possibly be an effective counterweight to the increase in Islam. He cited the case of the Balinese, who still upheld the caste system that was successful in keeping the Balinese as devout Hindus, delegating the political roles to the higher caste. Balinese did not, however, call for a separate nation. Based on that view, Hurgronje advocated the Ethical Policy that included two main issues: sending young Javanese aristocrats to the Netherlands for their studies, and giving colonial civil service jobs to the educated upper classes (Karim, 2006; Pringle, 2010).

The effect of more education among people of the upper classes was the increase in awareness of nationalism. Although they were becoming secular nationalist groups, they were able to cooperate with Islamic nationalist groups to fight for Indonesian freedom against Dutch colonialism. The earliest awakening movement was led by Mas Ngabehi Wahidin Sudirohusodo, a doctor from Yogyakarta who spread awareness and collected money to offer scholarships to local citizens in 1906. He promoted the idea of education for gifted children to achieve a better future. His ideas were supported by his colleagues from the M edical Faculty in Jakarta, and he established the first modern organisation named 'Budi Utomo' on May $20^{\text {th }}, 1908 .{ }^{17}$

Inspired by Budi Utomo, other local Islamic traders, RM Tirtoadisoerjo 
and Haji Samanhudi, started a new Islamic organisation called 'Sarekat Dagang Islam', then better known as Sarekat Islam (SI), in 1911 (Noer, 1990; Karim, 2006). The competition with Chinese traders and their arrogance towards local merchants were the reasons for the launch of this institution. SI was the first mass Islamic movement in Indonesia, having more than two million members by $1919 .{ }^{18}$

From 1918, SI had representatives in the Volksraad, the parliament during the Dutch colonial period. This opportunity opened channels for the Islamic voice to be heard by Dutch administrators. In 1923, SI changed its orientation from a traders' association to an Islamic political party. This party was first named Partai Sarekat Islam Indonesia (PSII). PSII was followed by other Islamic parties, such as Partai M uslimin Indonesia (Permi) in 1930, and Partai Islam Indonesia (PII) in 1938.

During this period, Deliar Noer (1990) classified Muslim activists into two groups: secular nationalists and Muslim nationalists. Secular nationalists were those who believed in Islam but tended to be neutral and tolerant to other values, and some of them ignored their religion's assertions. In contrast, Muslim nationalists were those who took Islamic thought as the reference for their movement.

Moreover, the rising number of educated Muslims also influenced the comprehension and practice of this religion. Deliar Noer (1990) differentiated between two main streams among Muslim groups: traditionalists and modernists. Traditionalists were those whose application of Islam was limited to that of the teaching of the Ulama, who lived from the seventh to the $13^{\text {th }}$ century. ${ }^{19}$ The traditionalists were those who focused on religious teaching and worship practices. For them, Islam was about figh (the rules of Islam), and they accepted taqlid (following the leader without criticising him) and refused ijtihad (decisions about solving contemporary problems that were not anticipated in the Qur'an, Sunnah, and ljma' - the Ulama's interpretations). ${ }^{20}$

The traditionalists tended to follow their Kyais (Islamic leaders) and totally devoted themselves to their leaders. For these groups, their Kyais had no sins, and the Kyai's statement was final: nobody may question it. ${ }^{21}$ This situation created an education system that focused more on memorising than understanding Islamic teachings. The followers did not have the courage to entertain different opinions than those of Kyais, and knowledge transfer tend to be a one-way communication process, with- 
out any discussion. Because they focused on religious matters, these groups generally did not become involved in politics. They were not anti-politics, but they were likely to limit themselves to their pesantrens, and spend their whole lives in them.

On the other hand, Noer (1990) argued the modernists had a more open attitude to the application of Islamic thought. Islamic teaching was not only deals with figh and practical worship, but it also had relevance to daily life. Islam was a universal teaching that could be applied to any time, any place, and under any condition. Islam was a reformed religion. It would not obstruct the exploration of knowledge, the development of science, or the position of women in society. Thus, Islam could be understood through a 'modern' lens.

The modernists, inspired by Muhammad Abduh's notion of a reform of Islam, only follow al Qur'an and Sunnah as the resources that inform their thinking. They believed that the ijtihad can still be opened wider, and they refused taqlid. ${ }^{22}$ The modernists believed that Islam offered freedom of thinking that could enhance the quality of a life led by Islamic values. This notion was contradictory to that of the traditionalists. litihad has led the modernists to pay attention to the argument, rather than to the one who has the argument. This is why the modernist teacher did not monopolise Islamic teaching, unlike in the case of the Kyai in traditionalists' view. The modernists agreed that Islamic discussion could be held outside of the pesantrens and mosques, and that Islamic teaching could be discussed, too. This view is contradictory to that of the traditionalists, who completely trust the man (the Kyai) who has the argument. Modernist M uslim leaders at that time were not only from Ulama, like Haji Rasul and $\mathrm{KH}$ Ahmad Dahlan, but were also businessmen, like Haji Abdullah Ahmad, Samanhoeddhi, and Ahmad Hasan. They were also aristocrats and cultural leaders, like Tjokroaminoto, Salim, Moeis, Natsir, as well as government administrators, like Gunaw an and Djajadiningrat.

Ahmad Dahlan pioneered the modernist Islamic movement. He established Muhammadiyah in 1912. His preaching about Islam attracted a wide range of people, from businessmen to educated people. His tolerance, kindness, and helpfulness made him easily accepted within the community. However, his initiative to revise kiblah, the direction of praying, generated a strong reaction from his seniors. Later on, M uhammadiyah focused its movement on establishing education and health centres in 
marginal societies.

Besides Muhammadiyah, modernists supported other Islamic organisations and political parties as well. The other modernist Islamic organisations were Syarekat Islam, AI-Irsyad, and Persatuan Islam (Persis). Some political parties that held Islam as their foundation were Partai M uslim Indonesia and Partai Islam Indonesia.

$\mathrm{NU}$, founded by Kyai Hasjim Asj' ari ${ }^{23}$, KH Abdul Wahab, and KH Bisri in 1926, was primarily established as a response to the growth of modernist Islam, and particularly Muhammadiyah. The fast-growing modern schools run by Muhammadiyah threatened the traditional pesantrens' existence at that time. Muhammadiyah had also loosened the Kyai-Santri relations, which was the main issue in NU traditions. The rivalry between both organisations prompted the dynamics of Islamic movements in Indonesia until the late 1900s.

In his book, Kuntowijowo (2008) stated that the NU movement was based on the agricultural Islamic traditions and on communal solidarity. This organisation attracted numerous participants mostly from rural areas because the Kyais joined it as their Islamic leaders. The NU had traditional institution networks that needed to avoid the influence of not only Muhammadiyah as the modernising movement, but also SI (which became PSII in 1923) as the political movement that had great influence on Indonesian Muslims at that time.

INDONESIAN MUSLIM GROUPS IN THE SUKARNO ERA (19451965)

The dominant issue in this era was the debate about the ideological foundation of this state after the Declaration of Independence on August $17^{\text {th }}, 1945$, when Sukarno became the first president of Indonesia. The contention took place between M uslims, Communists, and Nationalists. ${ }^{24}$ The conflict arose from debates about the constitution among politicians, and progressed to the Communist rebellion in 1948 and Darul Islam (DI/ TII) from 1948 to 1962; Sukarno's presidency had to be ended in 1965 when the biggest revolt by the Indonesian Communist Party occurred.

The debate about 'seven words' in the Jakarta Charter, which became the preamble of the Indonesian constitution, took more than 14 years to resolve through debate (Pringle, 2010; Boland, 1971). The seven words were the added phrase after 'Belief in God'. The phrase was 'dengan 
kewajiban menjalankan syari'at Islam bagi pemeluknya' (with the obligation for adherents of Islam to carry out Islamic law). The non-Muslim politicians rejected these words because they did not agree with the notion of an Islamic state, but the M uslim politicians argued that these words were only for M uslims and could be the foundation of law in Indonesia since Muslims constituted the majority religion in Indonesia. The debate was ended by President Sukarno when he launched the 'Decree of the President of Indonesia, Commander-in-Chief of the Armed Forces, with regard to the Return to the Constitution of $1945^{\prime}$ on July $5^{\text {th }}, 1959 .{ }^{25}$ By this decree, Sukarno dissolved the Constitutional assembly, the place where the debate on the Indonesian constitution took place.

Moreover, the unity of all Islamic groups, such as Muhammadiyah, $\mathrm{NU}$, and PSII, occurred through a change in the form of the Masyumi party in 1945. The establishment of Masyumi was based on the agreement of Kongres Umat Islam (the Congress of M uslims) on November $7^{\text {th }}$, 1945 in Yogyakarta. ${ }^{26}$ The basic objective of this party was to ensure that Islamic values were the foundation of Indonesia. Initially, this party was supported by all elements of Islamic groups that existed at the time; but the discordance within those cohorts could not be resisted, and internal disunity happened through the discharge of PSII and NU in 1947 and 1952, respectively. Finally, Sukarno dismissed Masyumi in August 1960 after he released his decree in July 1959.27

When Sukarno launched the Decree in July $5^{\text {th }}, 1959$, he started the new era of his presidency called 'Demokrasi Terpimpin' (Guided Democracy) until his fall in 1965. During this era, he dismissed the assembly and built a new 'parliament' with no ex-Masyumi activists there and eliminated most of the Islamic leaders who opposed him. He succeeded in marginalising Islamic leaders during his regime. However, NU was still allowed to join parliament and had the opportunity to support Sukarno in his cabinet. Wahid Hasjim, one of NU's leaders, was appointed as M inister of Religion in 1950. By his hand, Islam had the opportunity to spread more widely by establishing Islamic subjects in schools' curricula (including pesantrens, the traditional schools), from elementary schools to State Islamic Institutes.

Previously, while Masyumi and other Islamic leaders were active before they were dismissed by Sukarno, they succeeded in 1950 in introducing the Education by Law no. 4 of April $4^{\text {th }}, 1950$ article 20, which deter- 
mined that religious knowledge had to be taught in all state schools. Furthermore, the religious subjects must be delivered over two hours each week, beginning in the fourth year of elementary school. Since then, Islamic teaching has been boosted extensively all over Indonesia via state schools, not only inside the pesantrens, which were previously the only place in Indonesia to study Islam.

\section{Indonesian Muslim Groups in the New Order Era (1966 - 1998)}

According to Haedar Nashir (2013) in his book 'Islam Syari'at', the power of Muslim activists in Sukarno era was raised against the Indonesian Communist Party (Partai Komunis Indonesia or PKI), which had close relations with Sukarno in the last years of his presidency. ${ }^{28}$ The PKI was believed to have a mission to arrange a communist revolution to apply the world's communism dictatorship, which would turn Indonesia into an unreligious nation by reducing Pancasila (five pillars) into Ekasila (one pillar), that is gotong royong (mutual assistance).29 The PKI movement was terminated after its coup on Sukarno's presidency, which was known as G30S/PKI. ${ }^{30}$ After the bloody military response to the coup, and after the PKI was banned, Sukarno instructed Suharto to restore national security and Suharto took the role of the second Indonesian president.

Suharto's well-known objective was forging massive development in Indonesia under his 'orde baru' (New Order), especially in the economic sphere. In the beginning, Suharto brought a new hope for many Islamic leaders who had been repressed during Sukarno's era. However, such hopes were not fulfilled, given Suharto's political performance. In 1973, all four Islamic political parties that existed at that time were merged into one political party named Partai Persatuan Pembangunan (PPP, the Development Unity Party), which had no 'Islam' label in its name. ${ }^{31}$ Suharto also restricted the activities of all political parties (including PPP) under the Kabupaten or Kotamadya. ${ }^{32}$ This meant that there were no activities by political parties in rural areas that had direct contact with people in the lowest level of society. It could clearly be seen that Suharto wanted to limit the influence of political parties, and use 'Golongan Karya' as the only political tool to support his regime.

The other step that drew objections from most Islamic organisations in Indonesia was Suharto's decision about Pancasila as the only funda- 
mental ideology (asas tunggal) for all Indonesian institutions, including political parties and other Muslim organisations. This policy was legislated in the Government's regulation number 8 in 1985 about Social Organisations. There were numerous social organisations that continued to deny Pancasila as the only fundamental ideology of the nation, and this could cause serious social disintegration. As a consequence of this regulation, PPP had to change Islam to Pancasila as its fundamental ideology. This regulation also attracted other Islamic-based organisations that disagreed with it.

During the New Order era, some Islamic groups were established that originated from a transformation of previous M uslim activists or as a part of transnational Islamic movement networks. M uhammad Natsir was one of the examples of the movement of the existing Muslim activist. Natsir was the leader of Masyumi; he shifted hisfocus from politics to dakwah ${ }^{33}$ or an intensive program of religious predication ${ }^{34}$, following the limitations on the activities of Islamic parties. In M ay 1967, Natsir commenced Dewan Dakwah Islamiyah Indonesia (DDII, Indonesian Islamic M ission Council), an organisation that supports Islamic revitalisation and prohibits conversion of Muslims to other religions. Natsir also supported the establishment of Lembaga IImu Pengetahuan Islam dan Arab (LIPIA - the Islamic and Arabic Studies Institution), a branch of M uhammad bin Saud University from Saudi Arabia in 1990. This institution became the source of Islamic Wahabbi Salafism, which includes among its alumni some who became Salafi leaders (Bruinessen, 2002; Pringle, 2010). Later, Natsir and Abu Bakar Ba' asir were two important figures who supported the fundamentalist movement. Abu Bakar Ba'asyir was the heir to the Darul Islam movement that had been banned in 1962, and was alleged linked to Komando J ihad's activists who were behind 'terrorist' actions by bombing several churches, cinemas, clubs, and the Borobudur temple in the 1970 s and $1980 \mathrm{~s}^{35}$. After his release from jail and his return from M alaysia, Abu Bakar Ba'asyir found Pesantren Al Mukmin, the salafi school that was widely known as the 'radical' salafi. This pesantren is located at Ngruki, Solo (in central Java) and was founded in 1972. In post-Suharto era, Abu Bakar Ba'asyir was accused of being the leader of 'Jama'ah Islamiyah', which was responsible for several bombings in the early $2000 \mathrm{~s}$.

On the other hand, some new Islamic activists also emerged as a branch of international Islamic movements, such as the Muslim Brotherhood from 
Egypt and HTI from Jerusalem (Noorhaidi, 2012; Bruinessen, 2002). In the future, in the post-Suharto era, these transnational movements existed in political ${ }^{36}$ and non-political movements. ${ }^{37}$

Meanwhile, Nurcholis Madjid was one of the most important figures promoting Liberal Islam in Indonesia. His speech entitled 'The Necessity of Renewing Islamic Thought and the Problem of the Integration of the Umma', which was delivered on January $2^{\text {nd }}, 1970$, became the mark of the renewal movement (gerakan pembaharuan) in Islam. One of his controversial ideas was the 'Islam Yes, Islamic Party No!', which invited debates and protests from other Islamic activists. His way of confronting the 'mainstream' Islamic thought was criticised as 'impolite' according to senior Islamic leaders. A lot of Islamic leaders attacked his notions of 'secularism' and 'pluralism'.

Nurcholis Madjid is known as the 'bourgeois pluralist' for his belief that all religions in Indonesia should be considered as 'equal'. Madjid stated that the problem of pluralism in Islam was the problem of Muslim adaptation in this modern age, because Muslims could not assimilate to rapid changes in global society (Madjid, 1996). This statement drew the criticism from conservative Muslims that it could be used by Christians in their efforts to evangelise Christianity.

$M$ adjid became the father of tolerance and pluralism in Indonesia, and a number of modern Muslim scholars follow his concepts. His followers are mostly intellectual Muslims who have completed tertiary education. Madjid's notion seems to make sense when he tries to see Islamic teaching through a liberal interpretive lens. Most Islamic leaders (including the modernists) reject this approach because there are prescribed methods to interpret the Qur'an, one of which is incompatible with the liberal interpretive approach. Thirty years later, in 2001, Ulil Absar Abdala continued to promote his way of thinking through the Jaringan Islam Liberal (JIL, the network of Islamic liberation), which allows ordinary people to interpret Islam and offers ideas of a reform movement in Islamic teaching in Indonesia. This movement has provoked criticism from other Islamic leaders. These leaders state that this movement deviates from the original way of understanding Islam.

The growth of liberal followers, as well as followers of other Islamic thought, was caused by the growth of the economy, society, and policy under the New Order - an outstanding achievement of Suharto's. The 
New Order resulted in the growth of a powerful new middle class that was more educated and wealthier than before. William Liddle (1996) correlates this situation with the growth of 'creative' Islamic thinkers, whom Liddle labelled substantialists ${ }^{38}$ and the growth of 'reformist' scriptualists ${ }^{39}$.

Fachri Ali and Bachtiar Effendy classify four Islamic patterns in the New Order: Neo-Modernism, Socialist-Democracy, Internationalism or Islamic Universalism, and Modernism. ${ }^{40}$ Neo-Modernism is the viewpoint that marries Islamic values with modern conditions and processes without diluting basic Islamic values. The figures who support this view are Nurcholis $M$ adjid and Abdurrahman Wahid. The Socialist-Democracy standpoint calls for Islam to be the transforming power for all aspects of national life. Based on this notion, Islam should be considered in every socio-political process of change. Its innovators are Adi Sasono, M Dawam Raharjo, and Kutowijoyo.

The third pattern is Internationalism or Islamic Universalism. The Universalism group believes that Islam has universal values, including nationalism as long as this does not contradict fundamental Islamic teaching. Amien Rais, Jalaludin Rahmad, and Endang Saepuddin Anshari are the proponents of this view. The last pattern is Modernism, which emphasises the rationality of Islamic thought within the modern context. Ahmad Syafii $M$ a' arif advocates this stance.

Following the fall of the Indonesian rupiah by up to $70 \%$ relative to the US dollar over the course of six months in late 1997, a financial crisis was generated in Indonesia. This economic frustration became one of the reasons for political reformation instituted by Suharto's opponents, such as Megawati Sukarnoputri (daughter of Sukarno) and Amien Rais, the leader of Muhammadiyah. Suharto faced massive demonstrations against him by metropolitan university students and finally resigned his presidency, allowing Habibie, his vice-president, to take office in May 1998.

\section{Indonesian M uslims in the Early $21^{\text {st }}$ Century (1999 - 2010)}

The collapse of Suharto's 'New Order' regime of almost 32 years ushered in a new period of Indonesian history called 'orde reformasi' (Reformation Order). Indonesia became a prime example of a democratic shift in Muslim societies. ${ }^{41}$ Everybody, including Islamic groups, may express feelings and thought freely after the constraints imposed by Suharto had been dissolved. The most striking issues emerging in this era are the dis- 
course about radical Islam and the discussion about Jaringan Islam Liberal (JIL), which had been spearheaded by Nurcholis Madjid in the previous period.

Noorhaidi Hasan (2012) argues that the emergence of radical Islam in Indonesia is considered to be a response to Suharto's repressive handling of Muslim activists during his period, which resulted in the revolutionary idea to fight against the tyrant sovereignty. ${ }^{42}$ For example, the appearance of $\mathrm{M}$ ajelis $\mathrm{M}$ ujahidin Indonesia (M MI) is closely linked to the underground movement Negara Islam Indonesia (NII), which was banned in Sukarno's era. M MI held its first congress in 2000 as the mark of its establishment and chose Abu Bakar Ba'asyir as its leader. Yet, because Ba'asyir considered that M MI did not apply the Islamic norms in terms of leadership within the organisation, he quit M MI in October 2008 and formed a new organisation, Jama'ah Ashorut Tauhid (JAT).

Hasan (2012) and Bruinessen (2002) agreed that the other reason for the rise of Indonesian radical movements was rooted was the disappointment relating to the government's policy. An example pointed by Pringle (2010) is the militias formed by some Muslim leaders as a response to the slow reaction of government in handling conflicts in several places in Indonesia. Local conflicts involving religious issues took place in west and central Kalimantan from 1996 to 2001, Maluku and north Maluku from 1999 to 2004, and in Central Sulawesi from 1998 to 2007. Laskar J ihad ${ }^{43}$ and Jemaah Islamiyah ${ }^{44}$ were the militia formed to defend the Muslims in affected areas. Some members of these brigades had been former volunteers in Afghanistan's war to end Soviet occupation from 1979 to 1989.

The presence of Front Pembela Islam (FPI, Islamic Defender Front) found by Habib Rizieq Syihab in 1998 was also a response to the disappointment in government policy in handling the acts against Islamic values within the society. FPI's movement seeks to transform Muslim life from ignorance of living within Islam into a pure Islamic society. ${ }^{45} \mathrm{FPI}$ pursues its aims in controversial ways, such as closing bars, casinos, hotels, and other places that are viewed as offensive to the values of Islam.

Kuntowijoyo (2008) describes radicalism as being espoused by new fragment groups within Indonesian Muslim societies that emerge as an effect of globalisation. He mentions two kinds of fragment groups: religious fragment groups and political fragment groups. The religious fragment groups appear as a reaction to marginalisation processes and the 
style of modern life. Psychologically, they feel loss of control in dealing with new social processes. Sharpening social polarisation can cause these groups to mushroom in society. In the rural areas, polarisation removes them from the folds of communal solidarity, while in urban areas it tends to make people coalesce in groups bearing on rigid beliefs and characteristics. Both contexts push people to forge new social identities, which can be done through the making of new Islamic groups. Examples of this kind of group are Darul Hadits and Islam Jama'ah.

The second kind of fragmenting groups, according Kuntowijoyo (2008), is more political in character. These groups are usually still in the mainstream, but they try to isolate themselves or to be exclusive. They become radical because they are disappointed with their leaders' response to social and political change. On the other hand, those who are frustrated because of religious issues tend to be radical in actualising their goals. This radicalisation appears because they tend to be close-minded. Thus, their ability to analyse social facts is low. According to Kuntowijoyo (2008), radicalism is an emotional movement, without a thorough understanding of macro-social analysis.

By contrast, as a reaction to these radical movements, JIL or Liberalist Islam became more popular in the early $21^{\text {st }}$ century. Liberalism offered a new way of understanding Islam and was spread by Ulil Absar Abdala, a young Indonesian Islamic scholar and the founder of JIL. Abdala also introduced a new methodology in interpreting Islam. Normally it is only certain Ulama with certain qualifications who may interpret the content of the Qur'an. The qualifications are to guarantee that the mufassirin (the interpreter of the Qur'an) is a knowledgeable person and has credibility in applying Islamic values, so that his or her interpretation of the Qur'an will not deviate from the origin of Islamic teaching. In addition, the qualifications of the mufassirin have the purpose of ensuring the purity of Islamic teaching.

Abdala suggests a new methodology in interpreting the Qur'an. In early 2000 , Abdalla recommended a controversial ijtihadi methodology in assessing the Qur'an. ${ }^{46}$ According to him, everybody can interpret the Qur'an drawing on his or her own knowledge; there are no special requirements needed for interpretation. He also says that all religions are the same and that no religion is better than another. This means that every human being needs a religion, but that he or she does not have to 
be a M uslim, because Islam is the same as other religions. Abdala's other controversial notion is that syari'ah (Islamic Law) is a product of human history.

Abdala's controversial notion has drawn a striking reaction from most Islamic leaders. M edia Dakwah magazine (2004) accused JIL of being part of a Jewish-Zionist plot, because this network was sponsored by USAID. This fact was then used repeatedly to frame JIL as a member of 'a conspiracy' aimed at undermining Islam in Indonesia. MUI, the official Islamic leaders' assembly, finally released MUI Fatwa no. 7, 2005, which banned pluralism, liberalism, and secularism in Indonesian Islam. ${ }^{47}$

All in all, a variety of M uslim groups have been in existence in the postSuharto era. These groups range from militant to liberal Muslims. Taufik Abdullah (2013) defines militant M uslims as 'those who are intolerant to the variation of opinion about Islam'. Included in militant M uslim groups are FPI, Laskar Jihad, M MI, and HTI. On the other hand, liberal Muslims are those who have objective perspectives and admit that other religions are equal with Islam. The well-known Liberal Islam Network figures are Ulil Abshar Abdala and Lutfie Assyaukanie. On the other hand, moderate Muslim groups, which represent the majority of Muslims in Indonesia, are in the middle; they tend to tolerate various opinions but do not accept the notion that all religions are similar to Islam. NU and M uhammadiyah, two largest Muslim organisations in Indonesia, refer to themselves as moderate.

An example of the differences between militant and moderate Muslims is in the way they accept democracy applied in Indonesia. Noorhaidi Hasan (2012) argues that M ilitant M uslims perceived democracy as a system that does not exist in the two main references for M uslims: Al Qur'an and Sunnah. Democracy is interpreted as a thogut system, which produces leaders who are unfaithful to Islamic law (Arrahmah, February 23rd, 2013). Abu Bakar Ba'asyir, a militant Muslim leader, stated that the Indonesian government since the Sukarno era until now has been thogut, because it applied non-Islamic law, and led Indonesian Muslims to become detached from Islamic values and unfaithful to them. Upholding an Islamic state is an ideal goal for all Muslims to actualise Islamic Chaliph into reality. ${ }^{48}$ Since the M uslim activists reject democracy, they also refuse to participate in any elections held in Indonesia.

Conversely, Hasan (2012) states moderate Muslims tend to accept the 
idea of democracy and believe that it is a strategic system to promote good governance. Some moderate Muslim groups formed political parties after Suharto resigned, and the Reformation Order was begun. Haedar Nashir (2013) categorises Islamic political parties that were born at that time into two groups: the party with Islam as the official fundamental principle and the party with the support of M uslim society. Partai Persatuan Pembangunan (PPP, Development Unity Party), Partai Bulan Bintang (PBB, M oon-Stars Party), and Justice Party (PK, which then became Prosperous Justice Party, PKS) are examples of the first category. All of those parties have overtly declared to have Islam as their fundamental reference.

The second category comprises political parties with the support of the M uslim community. Partai Kebangkitan Bangsa (PKB, National Resurrection Party) is formed with the support of the NU community, while the Partai Amanat Nasioanal (PAN, National Mandate Party) is supported by the M uhammadiyah community. Both parties do not openly declare themselves to be Islamic parties, and they are more inclusive. Both parties allow non-M uslims to join. ${ }^{49}$

\section{A B rief H istory of Indonesian Muslim Media}

This sub-chapter aims to provide a brief history of Indonesian Muslim media, which followed the development of Muslim movements from the early $20^{\text {th }}$ century. Like the growth of M uslim groups affected by the social politics at that time, the dynamics of Muslim media also relate to the recent situation faced by Muslim organisations and their environment. Unfortunately, references about the history of M uslim media in Indonesia are limited compared to references about mainstream media. Therefore, this sub-chapter describes the Muslim media that existed from early $20^{\text {th }}$ century and relate them to the situational political dynamics and the role of Muslim groups during that time.

\section{The Emergence of Islamic Media in the Early 20th Century}

Deliar Noer (1990) mentioned the modern Islamic movements of the early 20th century developed from educational and social movements. As more M uslim scholars returned from their studies in the Middle East and Europe, there was more awareness among them of being occupied by the Dutch government, and they pioneered the nationalism and freedom movements among their societies. 
The first Indonesian M uslim media outlet was initiated by Haji Abdullah Ahmad, the Padangnese ulama, who became the leader of Jamaah Adabiah in Padang, West Sumatra in 1908. Al M unir, the name of the magazine that emerged in 1911, was inspired by Al-Imam magazine, the fortnightly magazine published in Singapore. Al-Imam was the first Islamic reform magazine in Southeast Asia from 1906 to 1909, and this magazine inspired Haji Abdullah Ahmad to create a similar medium in his hometown. The AI M unir content included Islamic teachings, the story of the prophet Muhammad, and translated articles about the international Islamic world - an particularly the Middle East - from Al-M anar magazine Cairo. Haji Abdullah Ahmad also initiated the news magazine Al Akbar (1913), and became editor of the religious desk at Sarekat Islam media, Al Islam, in 1916.

Sarekat Islam (SI) played an important role in expanding Islamic media during the 1900s until Indonesia's independence in 1945. HOS Tjokroaminoto and Haji Agus Salim, both important figures in Sarekat Islam, gave their full support in promoting Islamic media outlets during that time. Some media were officially administered by SI, such as Neraca (1916-1924), Hindia Baru (1924-1926), Laskar (1930-1932), and Fajar Asia $^{50}$ (1927-1930). Other Islamic media were not part of SI but were supported by Agus Salim and Tjokroaminoto, including Bendera Islam (1924-1927), Bintang Islam (1923-1926), Mustika (1931-1932), and Utusan Hindia (1914-1923) (Noer, 1990). Both individuals were known as respected figures in the struggle for Indonesia's independence.

M uhammadiyah and NU, as modernist and traditionalist M uslim groups that emerged during that time, also had internal media outlets. M uhammadiyah, the modern Muslim group, initiated several media outlets, such as Soeara Muhammadijah (1912), Adil (1932-1942), and Pancaran Amal (1936-1939), as well as some media collaborations between Muhammadiyah and SI figures, such as Bendera Islam (1924-1927) and Bintang Islam (1923-1926). NU also had its own internal media outlets, such as Utusan Nahdlatul Ulama (1928-1930), Swara Nahdhatul Ulama (1937-1941), and Berita Nahdlatul Ulama (1935-1940).

Beside M uhammadiyah and NU, some other M uslim organisations also had their own media outlets, such as AI-Lisan (1935) and Pembela Islam (1929-1933), owned by Persatuan Islam (Persis, Islamic Unity). Jong Islamieten Bond, the Muslim organisation whose members were those 
who had Dutch educational backgrounds, had Het Licht (The Light) (19251940).

Noer (1990) identified the content of Islamic media from 1900 until 1945 was varied. The content was not only about Islamic teachings; it also discussed other nations' circumstances. This fact is interesting, since at that time Indonesian audiences had limited access to information about other nations. Bintang Islam, AI Munir, and Suara Muslimin were three Islamic media outlets that discussed other nations' conditions, inspiring the audience to fight for independence against Dutch colonialism in Indonesia.

During World War II, there were political changes in Indonesia when Japan occupied Indonesia and took over Hindia Belanda authority. The Japanese occupation lasted from 1942 to 1945 . During that time, the Japanese government strictly oversaw the Indonesian papers by taking over all Dutch and Chinese media, and maintaining Japanese newspapers and magazines in the M elayu language, which carried Japanese propaganda in Indonesia (Smith, 1986). Unfortunately, there is insufficient reference available to explain what happened to Islamic media during the Japanese occupation.

\section{Islamic Media during Sukarno's Era (1945 - 1965)}

Sukarno's era lasted from Indonesia's Independence Day on August 17th, 1945 until he resigned as the first president in 1965. During that time, the shift in power in Indonesia was not only against the allied forces of the Netherlands and the UK, which wanted to return to Indonesia after the Japanese occupation; the power also spread among Indonesian nationalists, Islamists, and Communists to build power bases in forming a new independent Indonesia.

The Islamic media were also influenced by the situation at that time. Almost all M uslim activists were involved in politics, forming political parties like the PSII (Partai Sarekat Islam Indonesia from SI), which Muhammadiyah and NU activists later agreed to merge into one Islamic political party called M asyumi. To extend their political influence to broader Indonesian society, M asyumi published newspapers and magazines. Abadi is M asyumi's official newspaper that expresses the party's position to society. Abadi was founded in 1947 and has had a striking influence as Islamic media in the general society ever since. This influence can be seen 
from the re-birth of this newspaper in 1968, after it was banned in 1959, in line with the dismissal of Masyumi in the implementation of the 'Presidential decree' on July $5^{\text {th }}, 1959$. Abadi was banned for the second time in 1974, when it was accused of supporting the Malari tragedy. Malari was the first protest movement during Suharto's presidency, and was sponsored by university students in Jakarta. They protested against Suharto's ignorance of public policy, on January $14^{\text {th }}$ to $15^{\text {th }}, 1974$. Unfortunately, the demonstration led to the vandalism of hundreds of building, cars, and motorcycles, which were burned and ruined in the middle of Jakarta. ${ }^{51}$ Hariman Siregar, the leader of the protest, however, denied that students were responsible for all of the vandalism. The effects of the vandalism were too broad to have been causes solely by the student protest participants. Hariman believed that there must be a stronger agent who could have committed the vandalism.

Hefner (1997) summarises that Suharto used this tragedy to rid himself of Abadi, the biggest Islamic newspaper at that time. Besides newspapers, Masyumi's supporters also launched magazines that promoted Masyumi's aims. The two well-known magazines were Hikmah (19481958) and Pandji Masyarakat (1959-1961).

Masyumi significantly influenced the rise of Islamic media in Sukarno's era via its media outlets, which had become the main reference for M uslims on current issues. Smith (1986) recorded that the circulation of the Abadi newspaper was up to 17,000 per day. The momentous role that Masyumi had from 1945 until 1957 was not only in Islamic media, but also in Indonesian politics. Masyumi earned second place in the Indonesian general election in 1955, after Sukarno's party, PNI (Partai Nasional Indonesia, Indonesian National Party). Masyumi activists were also chosen to be involved in the cabinets. Therefore, even though this party had been dismissed by Sukarno in 1960, the ex-activists of Masyumi continued their struggles in different forms, such as via the DDII in Suharto's era.

\section{Islamic Media in the New O rder Era (1966 - 1998)}

The Islamic movements in Suharto's era, also known as the New Order Era, were limited. Suharto not only merged all Islamic parties into one party named 'Partai Persatuan Pembangunan', but he also removed the symbol of Islam in both the name and logo of the party. Suharto also forced all organisations - including Islamic organisations - to acknowl- 
edge Pancasila as the only fundamental ideology (asas tunggal) within their organisations.

In terms of media, Suharto enforced control systems that required all media to gather two kinds of licences, a printing permit and a publishing permit, for which in 1982 the Ministry of Information issued a new media permit called the Press Publication Enterp rise Permit or SIUPP..$^{52}$ All media had to possess a SIUPP in order to circulate their media to the general public. Since the large payment required for a SIUPP was up to $\$ 140,000$, only limited Islamic media outlets had a SIUPP at that time. According to Hefner's investigations, only Muhammadiyah owned a SIUPP. Therefore, the other Islamic media could not be displayed in general bookstores, and were only circulated among limited M uslim groups and societies.

Despite the strict censorship and limited publication access during the New Order Era, this era was also marked by the widened spectrum of Islamic movements, from fundamentalism to liberalism. This spectrum was also projected in Islamic media. Hefner (1997) mentions in his article that there were M edia Dakwah launched by DDII with a militant background, Suara Muhammadiyah managed by Muhammadiyah, with a moderate background, and Ulumul Qur'an, administered by Lembaga Studi Agama dan Filsafat (LSAF), which consists of liberal M uslim activists. In addition, Republika, The general Muslim newspaper whose stock was offered and owned by the Muslim public, was born under the initiative of Ikatan Cendekiawan M uslim Indonesia (ICM I), the new M uslim organisation supported by Suharto, founded in 1990.

Republika published its first newspaper on January $4^{\text {th }}, 1993$. The online version was launched on August $17^{\text {th }}, 1995$ and it became the first online newspaper in Indonesia. Republika is the first national newspaper that is acknowledged as an Islamic newspaper, because it was founded by ICM I and its initial investment was raised through shares being personally offered to Indonesian M uslims. ${ }^{53}$ Despite the ownership change to PT Mahaka Media, the newspaper's positioning as Islamic newspaper remains today.

\section{Isamic Media in the Early $20^{\text {th }}$ Century (1999 - 2010)}

The fall of Suharto became the momentum for media freedom, since the SIUPP regulation that limited media circulation was dropped during Habibie's era. Press regulation was changed to reflect a liberal press, after the previous regulation (law no 21/1980) had been dismissed and re- 
placed with the new law no. 40/1999. This new regulation limits the government's intervention in press freedom. Due to the new regulation, a myriad of new media emerged at that time. Based on Serikat Penerbit Surat Kabar (the Newspaper Publishers Association) data, up to 1997 there were 289 registered media, and this number skyrocketed to 1,687 in 1999. ${ }^{54}$ Islam media also followed this upward trend. Large numbers of Islamic magazines appeared; even though some of them might have existed in the Suharto era, at that time they could only be circulated to internal members. For example, there are some militant magazines from salafi backgrounds such as As Sunnah, Assyariah, An Nashihah, Fatwa, Qiblati, Nikah, and Elfata.

During this era, the internet as the new medium also began to spread among Indonesians. This new technology has also brought some changes in the landscape of Indonesian media. M uslim activists use the internet to spread more ideas about Islam and their concerns about their surroundings, which are related to their ideological backgrounds. Griffith et al. (2013) find that the violent ideological group websites use a variety of media to spread their ideological beliefs and may create a larger community of shared values than they presently have. These groups also highlight certain pictures and issues to create the affective process for indoctrination and maintenance of their group members. ${ }^{55}$ Sageman (2008) as cited by Bergin et al. (2009) - highlights the growth of community interest via internet initiated by the nature of anonymity among internet users, which leads them to disclose themselves easily via the internet, and to develop greater feelings of closeness among them. Therefore, to spread the ideological interests and to gather a wider society, many new websites with Islamic names and symbols have arisen since 2005. Some of those websites are salafy.or.id (2005), alsofwah.or.id, eramuslim.com (2005), arrahmah.com (2006), and Muslim.or.id (2008).

Some scholars have investigated the use of websites for spreading radical messages in Indonesia. Bergin et al. (2009), in a special report for the Australian Strategic Policy Institute published in March 2009, reported the number of internet users in Indonesia skyrocketed by $900 \%$ between 2000 and 2008. Bergin et al. also discovered that the number of websites with radical content increased drastically, from 15 in 2007 to 117 within a year. Within this report, Bergin identifies a variety of administrators of these radical websites: they are radical Muslim groups', pesantren's, and 
sympathetic groups' websites, which are run by groups of individuals with no links to any radical or extremist groups. ${ }^{56}$ In addition, Hui (2010) examines the radical websites description that frequently published the injustice concerned with the live threaten received by other M uslim jihadist and the compliment for martyrdoms. ${ }^{57}$

\section{CONCLUSION}

In conclusion, the development of Muslim groups in Indonesia was closely related to political changes and the struggle to of M uslims to earn recognition from the Indonesian authorities. Indonesian M uslim activists also played significant roles in the process of spreading awareness of nationalism during Dutch colonialism, as well as the struggle to achieve Indonesia's independence. Furthermore, they were actively involved in Sukarno's cabinet, until Sukarno took a stance against certain Muslim activists from M asyumi because of the allegations that they were involved in the Darul Islam rebellion that aimed to create an Islamic nation within Indonesia. After that, Indonesian M uslims became marginalised, even in Suharto's era. Muslim movements have existed since the fall of Suharto until and continue to exist today.

Islamic media emerged as one of the tools to spread M uslim organisations' ideas from the very beginning of the movements. Some of those media took the form of the official outlets of the organisations, seeking to create a commonality of views through the way in which news and issues were framed, while others were general media outlets with Islamic values embedded within news content. The form of the media also varied following the communication technology developments of the era.

\section{END NOTE}

1 Pew Forum on Religion \& Public Life (2011). The Future of the G lobal M uslim Population Projection for 2010 - 2030. Retrieved from http:// www.pewforum.org/ 2011/ 01/27/ thefuture-of-the-global-muslim-population/

2 Pringle, Robert. (2010). U nderstanding I slam in Indonesia Politics and D iversity. H onolulu: U niversity of $\mathrm{H}$ awai'i Press.

3 Laffan, M ichael. (2011). The M aking of Indonesian I slam 0 rientalism and the $N$ arration of Sufi Past. Princeton, N ew Jersey: Princeton U niversity Press.

4 Pringle, 2010

5 Madjid, Nurcholis. (1996). In Search of Islamic Roots for Modern Pluralism: The Indonesian Experience. In Woodward, M ark.(ed), Toward N ew Paradigm Recent D evelopments in Indonesian Islamic Thought (pp. 89-116). Tempe, A rizona: A ri- 
zona State U niversity.

6 Pringle, 2010

7 Maemunah, 2006

8 Madjid, 1996

9 Tenggeresse are the traditional communities that live on the slopes of Bromo mountain in East Java.

10 Kuntowijoyo. (2008). Paradigma Islam Interpretasi untuk A ksi. Bandung: Mizan M edia U tama

11 N oer, D eliar. (1990). G erakan M odern Islam di Indonesia 1900-1942. Jakarta: LP3ES

12 M uhammad Abduh (1849-1905) was an Islamic thought reformist from Egypt. Together with Jamal ad-D in Al A fgani (1839-1897), the Islamic Politics reformist, he published the Al'U rwat al-W ustqa magazine from Paris in 1884. This publication shocked the Islamic world as well as the Western world. British, Egyptian, and Indian administration destroyed and banned this magazine at that time.

13 N oer, 1990

14 N oer, 1990

15 Snouck H urgronje was a bureaucrat and scholar of I slam. H e had visited M ecca and met Indonesians there. He spoke and read Arabic and had completed an Islamic education in a Pesantren (traditional Islamic school in rural Indonesia).

16 Pringle, 2010

17 Karim, M A bdul. (2006). Kebangkitan Nasional: Analisis H istoris Peran Islam dalam Kebangkitan N asional. In M undzirin, Yusuf. (ed), Sejarah Peradaban Islam di Indonesia (pp. 224-259). Yogyakarta: Pustaka

18 Pringle, 2010

19 Dhofier, Zamakhsyari. (1982). Tradisi Pesantren, Pandangan H idup Kyai.Jakarta: LP3ES

20 Noer, 1990

21 Kuntowijoyo, 2008

22 Taqlid means following someone's statement about a matter about which one does not have enough knowledge (U tsaimin, A. S. (2007). Prinsip IImu U shul Figh. (A. S. Shilah, Trans.) Jakarta: Tholib). Q ur' an sura An N ahl ayah 43 stated "..so ask the followers of the Reminder if you do not know". This ayah explains that people have to ask to someone that knows and has knowledge about the matter of the question being asked.

23 Kyai H asjim Asj'ari and A hmad D ahlan were students of Syaikh A hmad Khatib when they studied Islam in M ecca from 1893 to 1905 (N oer, 1990).

24 A bdurrahman, 2006; Pringle, 2010; Bolland, 1971

25 Boland, BJ. (1971). TheStruggleof I slam in Indonesia. H olland: The H ague-M artinus Nijhoff.

26 A bdurrahman, 2006; Boland, 1971

27 Boland, 1971

28 N ashir, H aedar (2013). Islam Syariat Reproduksi Safiyah Ideologis di Indonesia. Bandung: Mizan

29 Suryanegara, A hmad M ansyur (2010). A pi Sejarah 2. Bandung: Salamadani

$30 \mathrm{G} 30 \mathrm{~S} / \mathrm{PKI}$ is stand for G erakan 30 September (September 30 $\left.0^{\text {th }}, 1965\right)$, the time 
when PKI coup Indonesian authority by kidnapping several general who were the leaders of Indonesian army.

31 The other $\mathrm{N}$ ationalist and C hristian-based partiesal so merged into PartaiD emokrasi Indonesia.

32 U ndang-U ndang No 3 tahun 1975 (Government regulation number 3, 1975) about Political Parties and Golongan Karya.

33 A rifin, S. (2006). Sejarah Partai Politik Islam Indonesia dari O rde Lama sampai O rde Reformasi. In M undzirin, Yusuf (ed), Sejarah Peradaban Islam di Indonesia (pp. 260-285). Yogyakarta: Pustaka

34 Undang-U ndang No 3 tahun 1975 (Government regulation number 3, 1975) about Political Parties and Golongan Karya.

35 Bruinessen, Martin Van. (2002). Genealogies of Islamic Radicalism in postSuharto Indonesia. South East A sia Research, 10 (2), 117-154

36 Hefner, Robert W. (2000). Civil I slam M uslims and D emocratization in Indonesia. Princeton, N ew Jersey: Princeton U niversity Press

37 Bruinessen, 2002

38 Islamic brotherhood in Indonesia formed the Justice Prosperous Party (Partai Keadilan Sejahtera, PKS) (N oorhaidi, 2012).

39 Hizbut Tahrir Indonesia and Salafy argued that democracy does not exist in Islamic teaching, and therefore joining political practices in Indonesia that apply a democratic system is against I slamic thought (N oorhaidi, 2012).

40 Substantialists view Islam as the content or basic belief, and view the practice as more important than the form. Substantialists believe that Muslims must be more tolerant of each other, and even of non-M uslims. They accept the current structure of government as the final form of the Indonesian state (Liddle, 1996). The Islamic leaders who hold this view are N urcholis M adjid and A bdurrahman Wahid.

41 Scriptualists view Islam as a set of Islamic law (syariah) that should be obeyed. Scriptualists always try to implement I slam as is done in the Q ur'an and Sunnah (the two fundamental Islamic resources). $\mathrm{N}$ atsir is one Islamic leader who follows this view.

42 Ali, Fachry. \& Effendy, Bahtiar. (1986). M erambah jalan baru Islam: rekontruksi pemikiran Islam Indonesia masa 0 rde B aru. Bandung: M izan

43 Hefner, Robert W. (2000). C ivil I slam M uslims and D emocratization in Indonesia. Princeton, N ew Jersey: Princeton U niversity Press

44 H asan, N oorhaidi (2012). I slam Politik di D unia K ontemporer K onsep G enealogi dan Teori. Yogyakarta: Suka Press

45 L askar Jihad was formed by Ja'far U mar Thalib, the leader of Salafi Pesantren in Yogyakarta, in A pril 2000. Laskar Jihad sent 7,000 troops to Maluku to help Muslims in that area (Bruinessen, 2002) (Pringle, 2010).

46 Jema'ah Islamiyah was founded by A bdullah Sungkar and Abu Bakar Ba'asyir in 1993 (Pringle, 2010). Bruinessen does not mention Jama'ah islamiyah in his article, but he mentions M ajelis M ujahidin, founded by Abdullah Sungkar and Abu BakarBa'asir.

47 Eliraz, G Ioria (2004). Islamic Radicalism in Indonesia: The G lobal and $\mathrm{H}$ istorical Context. Review of Indonesia and M alaysia Affairs, 38(1), 123-171 
48 Assyaukanie, Lutfi. (2008). Trajectories of Islamic liberalism in contemporary Indonesia. Australian Religion Studies Review, 21(2), 145-174. DOI: 10.1558/ arsr.v21i2.145.

49 Keputusan Fatwa M ajelis U lama Indonesia no. 7/ M unas V II/ M U I/ 11/ 2005

50 V ictoria, A di (2012). K hilafah TheA nswer C atatan I deologis Seputar D akwah Syariah $\&$ K hilafah. Yogyakarta: Kutilah M edia

51 N ashir, 2013

52 Fajar A sia was the official medium for Partai Sarekat I slam (Sarekat Islam Party), the transformation of SI to becomea political party on February $20^{\text {th }}, 1923$ (N oer, 1990).

53 Aliansyah, Muhammad A. (2014, January 15 $\left.{ }^{\text {th }}\right)$. M alari, Perlawanan Terhebat Pertama Terhadap Orde Baru. M erdeka online. Retrieved from http:/ / www.merdeka.com/ peristiwa/ malari-perlawanan-terhebat-pertama-terhadap-ordebaru-hariman-dan-malari-1.html

54 Aliansyah, Muhammad A. (2014, January $\left.15^{\text {th }}\right)$. M alari, Perlawanan Terhebat Pertama Terhadap Orde Baru. M erdeka online. Retrieved from http:// www.merdeka.com/ peristiwa/ malari-perlawanan-terhebat-pertama-terhadap-ordebaru-hariman-dan-malari-1.html

55 U tomo, Arif Punto (2010). Republika 17 tahun M elintas Jaman. Jakarta: H arian U mum Republika

56 Saptohadi, Satrio (2011). PasangSurut Kebebasan PersI ndonesia. Jurnal D inamika H ukum. Vol 11 (1): pp 127-138

57 Griffith, J.A., Byrne, C.L., N ei, D.S., Barret, J.D., H ughes, M.G., ... Mumford, M.D. (2013). O nline Ideology: A Comparison of Website Communication and $M$ edia U se. Journal of C omputer-M ediated C ommunication, 18, 137-153. D oi:10.1111/ jcc4.12003

58 Bergin A, O sman, SB, Ungerer C \& Yasin, NAM (2009). Countering Internet Radicalization in South East Asia, An RSIS - ASPI Joint Report, M arch 2009, Issue 22.

59 H ui, Jenifer Yang (2010). The internet in Indonesia, development \& Impact of Radical websites, Studies in Conflict and Terrorism. 33 (2). 171-191

\section{BIBLIOGRAPHY}

A rifin, S. 2006. Sejarah Partai Politik Islam Indonesia dari 0 rde Lama sampai 0 rde Reformasi. In Mundzirin, Yusuf (ed), Sejarah Peradaban Islam di Indonesia. Yogyakarta: Pustaka

A ssyaukanie, Lutfi. 2008. Trajectories of I slamic liberalism in contemporary Indonesia. A ustralian Religion Studies R eview, D O I: 10.1558/arsr.v21i2.145.

Bergin A, O sman, SB, Ungerer C \& Yasin, NAM.2009. C ountering Internet Radicalization in South East Asia, An RSIS - ASPI Joint Report, March 2009, Issue 22.

Boland, BJ. 1971. The Struggle of Islam in Indonesia. H olland: The $\mathrm{H}$ ague - M artinus Nijhoff

Bruinessen, M artin Van. 2002. G enealogies of I slamic Radicalism in post-Suharto I ndonesia. South E ast A sia Research 
D hofier, Zamakhsyari.1982. Tradisi Pesantren, Pandangan H idup Kyai. Jakarta: LP3ES Eliraz, G loria. 2004. Islamic Radicalism in Indonesia: The G lobal and H istorical C ontext. Review of Indonesia and M alaysia A ffairs

Griffith, J.A., Byrne, C.L., N ei, D.S., Barret, J.D., H ughes, M .G., Mumford, M.D. 2013. O nlinel deology: A Comparison of W ebsite Communication and M edia U se. Journal of Computer-M ediated Communication. D oi:10.1111/ jcc4.12003

H asan, N oorhaidi. 2012. I slam Politik di D unia K ontemporer K onsep $G$ enealogi dan Teori. Yogyakarta: Suka Press

H efner, Robert W. 2000. C ivil Islam M uslims and D emocratization in Indonesia. Princeton, $\mathrm{N}$ ew Jersey: Princeton U niversity Press

H ui, Jenifer Yang 2010. Theinternet in Indonesia, development \& Impact of Radical websites, Studies in Conflict and Terrorism.

Karim, M Abdul. 2006. Kebangkitan Nasional: Analisis H istoris Peran Islam dalam $\mathrm{K}$ ebangkitan N asional. In M undzirin, Yusuf. (ed), Sejarah Peradaban Islam di Indonesia (pp. 224-259). Yogyakarta: Pustaka

Keputusan Fatwa M ajelis U lama Indonesia no. 7/ M unas VII/ MU I/ 11/2005Victoria, A di.2012. K hilafah The Answer Catatan Ideologis Seputar Dakwah Syariah \& K hilafah.Yogyakarta: Kutilah M edia

Kuntowijoyo. 2008. Paradigma Islam Interpretasi untuk A ksi. Bandung: Mizan M edia U tama

Laffan, M ichael. 2011. The M aking of Indonesian I slam 0 rientalism and the $\mathrm{N}$ arration of Sufi Past. Princeton, N ew Jersey: Princeton U niversity Press.

M adjid, N urcholis.1996. In Search of I slamic Roots for M odern Pluralism: The Indonesian Experience. In Woodward, M ark.(ed), Toward N ew Paradigm Recent D evelopments in Indonesian Islamic Thought (pp. 89-116). Tempe, A rizona: A rizona State U niversity.

M uhammad Abduh. 1849-1905 was an Islamic thought reformist from Egypt. Together with Jamal ad-D in AI A fgani.1839-1897, the Islamic Politics reformist, he published the A I'U rwat al-W ustaa magazine from Paris in 1884. This publication shocked the Islamic world as well as the W estern world. British, Egyptian, and Indian administration destroyed and banned this magazine at that time

Nashir, H aedar. 2013. Islam Syariat Reproduksi Safiyah Ideologis di Indonesia. Bandung: Mizan

Noer, D eliar. 1990. G erakan M odern Islam di Indonesia 1900-1942. Jakarta: LP3ES

Pringle, Robert. 2010. Understanding I slam in Indonesia Politics and D iversity. H onolulu: U niversity of $\mathrm{H}$ awai'i Press.

Saptohadi, Satrio.2011. Pasang Surut K ebebasan Pers Indonesia. Jurnal Dinamika Hukum. Vol 11

Suryanegara, A hmad M ansyur. 2010. A pi Sejarah 2. Bandung: Salamadani

U ndang-U ndang No 3 tahun 1975 (G overnment regulation number 3, 1975) about Political Parties and $\mathrm{G}$ olongan K arya.

U tomo, A rif Punto.2010. Republika 17 tahun M elintas Jaman. Jakarta: $\mathrm{H}$ arian U mum Republika 